\title{
Immunofluorescence staining for the diagnosis of herpes encephalitis
}

\author{
A. H. TOMLINSON, I. J. CHINN, AND F. O. MacCALlUM \\ From the Public Health Laboratory and Virology Laboratory, Radcliffe Infirmary, Oxford
}

SYNOPSIS Direct immunofluorescence staining for herpes simplex virus was applied to cryostat sections of 43 specimens removed at brain biopsy. Herpes antigen was found in 10 specimens and virus was isolated from them. Antigen was found in one specimen from which virus was not isolated. Two specimens from which virus was isolated gave equivocal fluorescence. Thirty specimens gave no fluorescence or live virus. Immunofluorescence provided a diagnosis in three hr compared with $24-42 \mathrm{hr}$ for virus isolation.

Indirect immunofluorescence staining was applied to sections of brain removed at necropsy and fixed in formalin. Herpes antigen was found in sections of six of the 12 brains examined.

Over the past 10 years there has been a growing awareness of the encephalitis caused by herpes simplex virus, and the most recent survey (Illis and Gostling, 1972) shows that the mortality of untreated cases may be as high as $70 \%$ and that survivors are frequently left with serious physical and mental disabilities.

Dodge and Cure (1956) made the first attempt, unsuccessfully, to culture herpes virus from brain tissue removed at biopsy as a diagnostic procedure. The isolation of virus from biopsy brain tissue of four patients was described by MacCallum, Potter, and Edwards (1964) and similar results have been reported by many other groups (Miller, Hesser, and Tompkins, 1966; Rawls, Dyck, Klass, Greer, and Herrman, 1966; Breeden, Hall, and Tyler, 1966; Evans, Gray, Miller, Jones, Weeks, and Wells, 1967; Miller and Ross, 1968; Rappel, DuboisDalcq, Sprecher, Thiry, Lowenthal, Pelc, and Thys, 1971). The need for rapid diagnosis became pressing when chemotherapy of herpes encephalitis was introduced, first iodo-deoxyuridine (Breeden, Tyler, and Hall, 1966) and later cytosine arabinoside (Juel-Jensen and MacCallum, 1972).

In 1966 we began to apply immunofluorescence staining for herpes simplex virus to all tissue from brain biopsies sent to the laboratory and we reported preliminary results (Tomlinson and MacCallum, 1969). Flewett (1973) described the examination of tissue from the temporal lobes of 19 patients, 12 of which yielded herpes virus and 10 were rapidly diagnosed by immunofluorescence staining.

\footnotetext{
Received for publication 2 April 1974.
}

We now describe our experience with 43 biopsy specimens submitted for virological examination. We have also used the technique of Sabin and Messore (1961) for immunofluorescent staining of herpes virus antigen in paraffin sections of formalinfixed brain from 12 patients.

Materials and Methods

TISSUE

Fresh brain tissue removed at craniotomy or burrhole exploration was received from 40 patients in the Radcliffe Infirmary, from one patient in Bristol, and from two patients in London. Two of these specimens from other hospitals were received four $\mathrm{hr}$, and the third $20 \mathrm{hr}$, after operation. Many of the biopsies had been performed to differentiate between tumour, abscess, or viral encephalitis and some, when the clinical indications were strong, to confirm a suspected encephalitis. Each specimen was divided into three for histological examination, for virus culture, and for immunofluorescence. Formalin-fixed brain, from the Neuropathology Laboratory, Radcliffe Infirmary, or referred from other hospitals, was received as $6 \mu \mathrm{m}$ sections, still in paraffin, on slides.

CULTURE FOR VIRUSES

The tissue was ground in maintenance medium and $0.2 \mathrm{ml}$ volumes of the suspension were inoculated onto three to six tubes of primary human amnion cells and two tubes of secondary monkey kidney cells. After centrifuging off the debris the fluid was used to inoculate further cultures and suckling mice. 
PREPARATION OF SECTIONS

Biopsy tissue, usually a $2-3 \mathrm{~mm}$ cube, was blocked in $10 \%$ gelatin, snap frozen, and $6 \mu \mathrm{m}$ sections were cut in a cryostat, dried in air, and fixed in acetone for 10 minutes.

Sections of formalin-fixed tissue, also $6 \mu \mathrm{m}$, were dewaxed in xylene, taken through alcohol to water, and washed in several changes of buffered saline for four hours.

\section{IMMUNOFLUORESCENCE}

\section{Serum}

The antigen for immunizing rabbits was made by growing type 1 herpes virus in $6 \mathrm{oz}$ bottles of RK 13 cells for 48 hours. The medium was discarded and the cells were 'suspended in $0.5 \mathrm{ml}$ distilled water/bottle, frozen, thawed, and disrupted with ultrasonic energy. Antigen used for the first injection was incubated at $37^{\circ} \mathrm{C}$ for $18 \mathrm{hr}$ with $0.017 \%$ formaldehyde to inactivate the virus. Intramuscular injections were given: day $0,0.25 \mathrm{ml}$ inactivated antigen plus incomplete Freund's adjuvant; day 56, $0.25 \mathrm{ml}$ 'live' antigen with adjuvant; day $84,0.5 \mathrm{ml}$ antigen; day $112,0.5 \mathrm{ml}$, and the animals bled 10 days later. The serum had a complement-fixation titre of $1: 800$ and for indirect immunofluorescencestained, acetone-fixed herpes virus at $1: 80$ or $1: 160$.

\section{Conjugated antibody}

A crude globulin fraction was separated from the serum by dialysis against $1.56 \mathrm{M}$ ammonium sulphate, labelled with fluorescein isothiocyanate and freed from unreacted fluorescein on a column of Sephadex G-25. Before use it was absorbed three times with an homogenate of guinea pig liver.

\section{Staining}

For the fresh tissue the absorbed conjugate was diluted 1:10 in normal rabbit serum as test reagent, and $1: 10$ in unlabelled anti-herpes rabbit serum for the blocking control. Test and control reagents were applied, to at least three sections each, for 30 min at room temperature. After washing the sections were mounted in buffered glycerol.

Sections of formalin-fixed tissue were treated with a 1:20 dilution of either unlabelled antiherpes serum (test) or of normal rabbit serum (control) for $60 \mathrm{~min}$ at room temperature. After washing, the sections were overlaid with a 1:40 dilution of fluorescein-conjugate swine antirabbit globulin (Nordic Diagnostics) for $20 \mathrm{~min}$, re-washed and mounted.

As a final check on specificity, some specimens of formalin-fixed tissue were stained with absorbed antiherpes serum thus: $0.2 \mathrm{ml}$ antiserum was diluted to $2.0 \mathrm{ml}$ and absorbed with BHK-21 cells, from a Roux bottle, for two hr at $37^{\circ}$. Another $0.2 \mathrm{mb}$ was absorbed with herpes-infected BHK-21 cells The cells were centrifuged off, the absorbed seras were heated at $56^{\circ}$ for $30 \mathrm{~min}$ and diluted two-fold for indirect staining as above.

\section{Microscopy}

Preparations were examined under a Vickersu Patholette microscope with halogen quartz illumination and an interference filter (Barr and Stroud)? The Vickers $\times 20$ panchromatic objective, NA $0.65 \overrightarrow{\vec{t}}$ combined adequate magnification with a brigh image.

\section{Results}

TISSUE REMOVED AT BIOPSY

The results on the 43 specimens are summarized ing table I. Immunofluorescence staining of the sections from 10 cases showed unequivocal evidence of herpes simplex virus antigen. Sections treated with the test reagent showed brightly fluorescent neuronesand glial cells, many per section of some specimens (fig 1 and table II), whereas the control staining ${ }^{+}$ produced either no fluorescence at all or a jus discernible coloration (fig 2). Cultures of thes specimens from these 10 cases all yielded herpeso simplex virus.

Despite the convincing demonstration by immuno® fluorescence of viral antigen in the specimens from $\overrightarrow{5}$ case 9, virus was not grown from that specimen. The patient had been only mildly ill for 16 days before the biopsy was performed and at that date the titre of complement-fixing antibody was already $1: 51$. in serum and 1:64 in cerebrospinal fluid. The histopathological diagnosis from the biopsy tissue was necrotizing encephalitis. It appears that ims munofluorescence detected remaining antigen from an infection already terminated by the host'sิ defences, at the time of biopsy.

The two cases listed in table I as 'culture positive immunofluorescence doubtful' illustrate the limi tations of the technique. The sections from case $\mathfrak{b}$

\begin{tabular}{lcll}
\hline Results of Tests & $\begin{array}{l}\text { No. of } \\
\text { Cases }\end{array}$ & Final Diagnosis \\
\hline $\begin{array}{l}\text { Immunofluorescence positive } \\
\text { Virus isolation positive }\end{array}$ & 10 & HSV encephalitis \\
$\begin{array}{l}\text { Immunofluorescence positive } \\
\text { Virus isolation negative }\end{array}$ & 1 & HSV encephalitis \\
$\begin{array}{l}\text { Immunofluorescence doubtful } \\
\text { Virus isolation positive }\end{array}$ & 2 & HSV encephalitis \\
$\begin{array}{l}\text { Immunofluorescence negative } \\
\text { Virus isolation negative }\end{array}$ & 30 & $\begin{array}{l}\text { Other than } \\
\text { HSV encephalitis }\end{array}$ \\
\hline
\end{tabular}

Table I Correlation of immunofluorescence tests and virus isolation with final diagnosis 


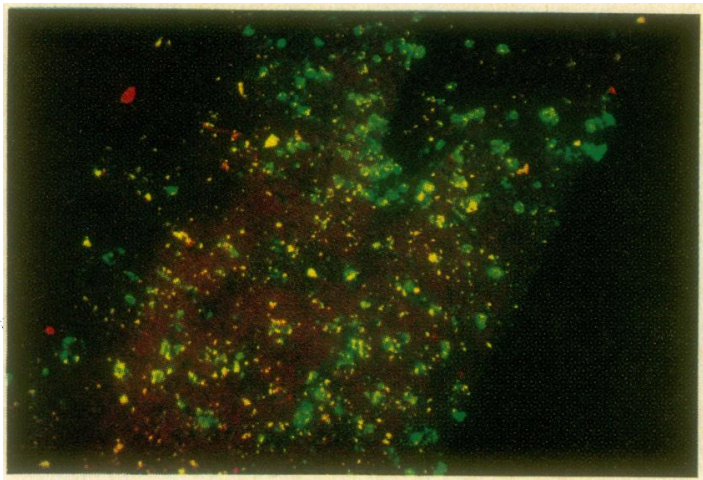

Fig 1

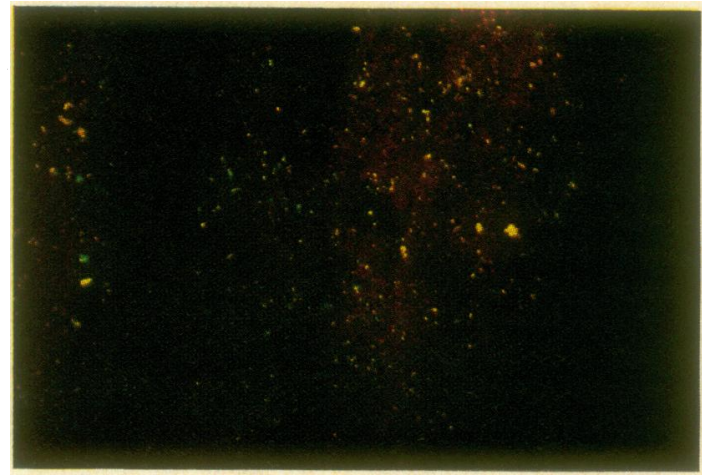

Fig 2

Fig 1 Test staining of biopsy tissue from case 11. $\times 160$ Green areas: antigen containing cells. Yellow flecks: autofluorescence of lipofuchsin.

Fig 2 Control staining of biopsy tissue from case 11. $\times 160$

\begin{tabular}{|c|c|c|c|c|}
\hline \multirow{2}{*}{ Case No. } & \multirow[t]{2}{*}{ Site of Biopsy } & \multirow[t]{2}{*}{ No. of Fluorescent Cells/Section } & \multicolumn{2}{|c|}{ Herpes Virus } \\
\hline & & & Isolated & $\begin{array}{l}\text { Time to Isolation } \\
(\mathrm{hr})\end{array}$ \\
\hline 1 & R. temporal & 2, 1 (equivocal) & + & 42 \\
\hline 2 & R. frontal & 16,22 & + & 24 \\
\hline \multirow[t]{3}{*}{3} & R. frontal & 7,4 & + & 42 \\
\hline & L. frontal & 10,12 & + & 42 \\
\hline & L. temporal & Many, many, many & 4 & 42 \\
\hline 4 & L. temporal & 24 , many, many & + & 42 \\
\hline 5 & L. temporal & Many, many, many & + & 42 \\
\hline 6 & temporal & $28,32,33$ & + & 42 \\
\hline 7 & Not known & $1,1,1$ & + & 42 \\
\hline 8 & R. temporal & $2,6,3,4$ & + & 18 \\
\hline 9 & L. temporal & $3,10,2$ & - & \\
\hline 10 & R. temporal & Many, many, many & + & 24 \\
\hline \multirow[t]{2}{*}{11} & R. temporal deep & Many, many, many & + & 24 \\
\hline & superficial & Many, many, many & + & 24 \\
\hline 12 & L. temporal & Many, many, many & + & $96^{1}$ \\
\hline 13 & frontal & Many, many, many & + & 42 \\
\hline
\end{tabular}

Table II Numbers of fluorescent cells in and time to isolation of virus from biopsy specimens ${ }^{1}$ Specimen received $20 \mathrm{hr}$ after operation

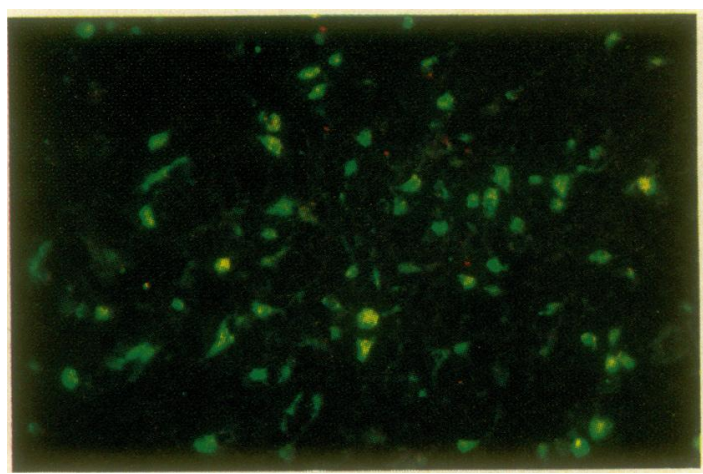

Fig 3 Test staining of formalin-fixed brain. $\times 160$

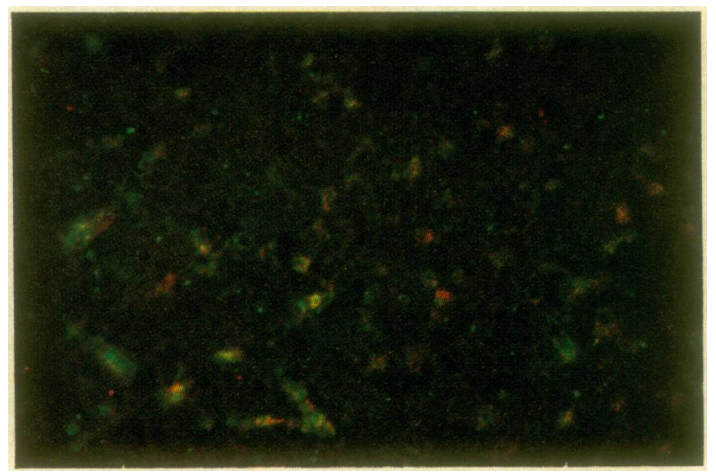

Fig 4 Control staining of formalin-fixed brain. $\times 160$ 
were examined before our technique had been standardized; a less potent antiserum was used and an inefficient fluorescence microscope employed so that a firm diagnosis had to await the isolation of virus. The sections from case 7 each contained only one fluorescent cell in the test staining, and although no fluorescence was seen in the controls, this was deemed inadequate for a firm diagnosis. As cultures from this specimen revealed only a single focus of infection in one of the five tubes inoculated it was apparent that the sample had come from the edge of the infected area.

From 30 cases the specimens showed no evidence of herpes virus antigen and virus was not isolated. The final diagnoses of these patients was disease other than herpes encephalitis.

The time elapsing between operation and the first appearance of cytopathic change in tissue cultures (table II), not including time for a neutralization test, ranged from 18 to $72 \mathrm{hr}$, so that the immunofluorescence technique materially speeded diagnosis.

\section{POSTMORTEM TISSUE FIXED IN FORMALIN}

Eleven of the specimens examined were from cases suspected to be herpes simplex encephalitis on clinical or histopathological grounds, but the brain had not been cultured for virus. Immunofluorescence staining revealed antigen containing neurones (fig 3 ) in five of these specimens, with no staining of such cells in the controls (fig 4). With formalin-fixed tissue the control staining was particularly important as nonspecific staining of meninges and the walls of blood vessels was often prominent. When supposedly specific staining was found it was essential to determine, under a low-power objective, its exact location in the section, and then check the same area of the control section for absence of fluorescence.

A typical example of the use of this technique was in the case of an 11-yr boy with a life-long history of a neurological disorder, who died after an acute febrile illness lasting 14 days. Herpes encephalitis had not been suspected in life but the histopathology was found to be that of necrotizing encephalitis. Immunofluorescence staining revealed herpes antigen in cells of the hippocampus.

The twelfth specimen was from a brain, the temporal lobes of which had been sampled at necropsy and shown by culture to contain virus. After the brain had been fixed in formalin the appearance of stained sections suggested the presence of infection in the midbrain and immunofluorescence provided confirmation.

\section{Discussion}

As indicated in the introduction, brain biopsy is
A. H. Tomlinson, I. J. Chinn, and F. O. Maccallum widely used for the diagnosis of herpes encephalitis and when brain tissue has been removed the use of: immunofluorescence provides a diagnosis in two to three hr compared with 24 to $72 \mathrm{hr}$ for virus isolation $\overrightarrow{-}$ In our hands it gave no false positives with $30 \bar{E}$ specimens. The only equivocal fluorescence of acs. virus-containing specimen was due to the poor巾 serum first used. The small amount of fluorescence $\frac{\varrho}{, 0,}$ and of virus, in one specimen was a consequence of unfortunate sampling of the brain so that immuno- $\overrightarrow{0}$ fluorescence gave no false negatives.

The cutting of frozen sections is more time consuming than the preparation of smears or imprints. and, as Flewett (1973) has pointed out, there is some risk to the operator from an infected knife. Despite. these considerations we believe that sections are preferable because, being thin and uniform and because infected cells occur at the same sites, testo and control staining can be carefully compared, $a_{-}$ matter of some importance when there are only fewc infected cells. The risk of accidental infection is no greater than that incurred by a surgeon or histo-pathologist handling herpes-infected brain.

The direct staining technique was chosen for: ${ }^{+}$ biopsy tissue because it is quicker and gives less nonspecific staining than the indirect technique, but for formalin-fixed tissue the greater sensitivity of the indirect method was necessary.

Although formalin-fixed tissue exhibits more non- $\frac{\stackrel{\circ}{\odot}}{2}$ specific fluorescence than fresh tissue the absorption $-\overrightarrow{\vec{A}}$ with-antigen procedure provides a certain identifica- $\frac{\text { 을 }}{3}$ tion of specific staining. If brain cells in a section fluoresce when treated with BHK-cell absorbedo․ serum and similar cells, in the same area of the adjacent section, do not fluoresce after treatmento with serum absorbed with herpes-infected BHK cells, the fluorescence must be due to herpes antigen in the brain cells.

When applied to sections of formalin-fixed tissue immunofluorescence brings immunological specifi- $⿱ 乛$ city to a diagnosis otherwise resting on histology and $D$ the morphology of particles under the electron microscope. The tissues reported here had been $N$ embedded for only weeks or a few months, but the technique will detect herpes antigen in tissue years $\mathrm{N}$ after embedding (Sabin and Messore, 1961; Tom- $\mathrm{W}$ linson, 1970).

\section{References}

Breeden, C. J., Hall, T. C., and Tyler, H. R. (1966). Herpes simplex $\stackrel{\mathscr{D}}{-}$ encephalitis treated with systemic 5-iodo-2'deoxyuridine. $\square$ Ann. intern. Med., 65, $1050-1056$.

Dodge, P. R., and Cure, C. W. (1956). Acute encephalitis with intra- $\frac{O}{\square}$ nuclear cellular inclusions. New Engl. J. Med., 255, 849-853.

Evans, A. D., Gray, O. P., Miller, M. H., Jones, E. R. V., Weeks, R. D., and Wells, C. E. C. (1967). Herpes simplex encephalitis Q treated with intravenous idoxuridine. Brit. med. J., 2, 407-410. $\sigma$

Flewett, T. H. (1973). The rapid diagnosis of herpes encephalitis. Postgrad. Med. J., 49, 398-400. 
Illis, L. S., and Gostling, J. V. T. (1972). Herpes Simplex Encephalitis. Scientechnica, Bristol.

Juel-Jensen, B. E., and MacCallum, F. O. (1972). Herpes Simplex, Varicella and Zoster. Heinemann, London.

MacCallum, F. O., Potter, J. M., and Edwards, D. H. (1964). Early diagnosis of herpes simplex encephalitis by brain biopsy. Lancet, 2, 332-334.

Miller, J. K., Hesser, F., and Tompkins, V. N. (1968). Herpes simplex encephalitis: report of 20 cases. Annal. intern. Med., 64, 92-103.

Miller, J. D., and Ross, C. A. C. (1968). Encephatitis: a four year survey. Lancet, 1, 1121-1126.

Rappel, M., Dubois-Dalcq, M., Sprecher, S., Thiry, L., Lowenthal, A., Pelc, S., and Thys, J. P. (1971). Diagnosis and treatment of herpes encephalitis. a multidisciplinary approach. J. neurol.
Sci., 12, 443-458.

Rawls, W. E., Dyck, P. J., Klass, D. W., Greer, H. D., and Herrman, E. C. (1966). Encephalitis associated with herpes simplex virus. Ann. intern. Med., 64, 104-115.

Sabin, A. B., and Messore, G. (1961). Fluorescent antibody technique in the study of fixed tissues from patients with encephalitis. In Encephalitis, edited by L. van Bogaert, J. Radermecker, J. Hozay, and A. Lowenthal, pp. 621-626. Elzevier, Amsterdam. Tomlinson, A. H. (1970). Demonstration of herpes simplex viral antigen by immunofluorescence. J. clin. Path., 23, 29-30.

Tomlinson, A. H., and MacCallum, F. O. (1969). Virological diagnosis. In Virus Diseases and the Nervous System, edited by C. W. Whitty, J. T. Hughes, and F. O. MacCallum, pp. 21-27. Blackwell, Oxford.

\section{Reports and Bulletins prepared by the Association of Clinical Biochemists}

The following reports and bulletins are published by the Association of Clinical Biochemists. They may be obtained from The Publishing Department, British Medical Journal (ACB Technical Bulletins) B.M.A. House, Tavistock Square, London WC1H 9JR. Overseas readers should remit by British Postal or Money Order.

SCIENTIFIC REPORTS (price $£ 1 \cdot 00 / \$ 2.00$ each)

3 Automatic Dispensing Pipettes: an assessment of 35 commercial instruments September 1967 P. M. G. BROUGHTON, A. H. GOWENLOCK, G. M. WIDDOWSON, and K. A. AHLQUIST

4 An Evaluation of five Commercial Flame Photometers suitable for the Simultaneous Determination of Sodium and Potassium March 1970 P. M. G. BROUGHTON and J. B. DAWSON

SCIENTIFIC REVIEWS (price $£ 1 \cdot 00 / \$ 2.00$ each)

1 The Assessment of Thyroid Function March 1971 F. V. FLYNN and J. R. HOBBS

2 Renal Function Tests Suitable for Clinical Practice January 1972 F. L. MITCHELL, N. VEALL, and R. W. E. WATTS

TECHNICAL BULLETINS (price $£ 1.00 / \$ 2.00$ each)

9 Determination of Urea by AutoAnalyzer November 1966 RUTH M. HASLAM

11 Determination of Serum Albumin by AutoAnalyzer using Bromocresol Green October 1967 B. E. NORTHAM and G. M. WIDDOWSON

13 An Assessment of the Technicon Type II Sampler Unit March 1968 B. C. GRAY and G. K. MCGOWAN

14 Atomic Absorption Spectroscopy: an outline of its principles and a guide to the selection of instruments May 1968 J. B. DAWSON and P. M. G. BROUGHTON

15 A Guide to Automatic Pipettes (2nd edition) June 1968 P. M. G. BROUGHTON

16 A Guide to Automation in Clinical Chemistry May 1969 P. M. G. BROUGHTON

17 Flame Photometers: a comparative list of 17 instruments readily available in Britain August 1969 P. WILDING
19 Spectrophotometers: a comparative list of low-priced instruments readily available in Britain May 1970 C. E. WILDE and P. SEWELL

20 Quantities and Units in Clinical Biochemistry June 1970 P. M. G. BROUGHTON

21 Filter Fluorimeters: A comparative list of 18 instruments September 1970 H. BRAUNSBERG and $s$. $s$. BROWN

22 Bilirubin Standards and the Determination of Bilirubin by Manual and Technicon AutoAnalyzer Methods January 1971 BARBARA BILLING, RUTH HASLAM, and N. WALD

23 Interchangeable Cells for Spectrophotometers and Fluorimeters September 1971 S. S. BROWN and A. H. GOWENLOCK

24 Simple Tests to Detect Poisons March 1972 B. w. MEADE et al.

\section{Blood Gas Analysers May 1972 K. DIXoN}

26 Kits for Enzyme Activity Determination September 1972 S. B. ROSALKI and D. TARLOW

27 Assessment of Pumps Suitable for Incorporation into Existing Continuous Flow Analytical Systems November 1972 A. FLECK et al.

28 Routine Clinical Measurements of Transferrin in Human Serum September 1973 K. DIXON

29 Control Materials for Clinical Biochemistry (5th edition) September 1973 J. F. STEVENS

30 Notes on the Quality of Performance of Serum Cholesterol Assays September 1973 s. S. BROWN 